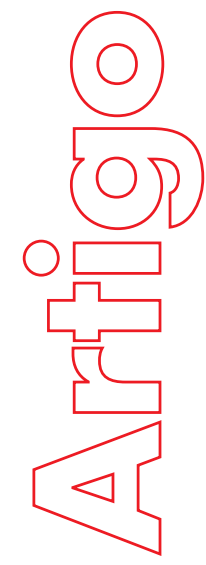

\title{
AFRICANIZED SPACES IN BRAZIL: SOME REFERENCES OF RESISTANCE, SURVIVAL AND REINVENTIONS
}

\section{Rafael Sanzio Araújo dos Anjos}

p. $35-47$

revista

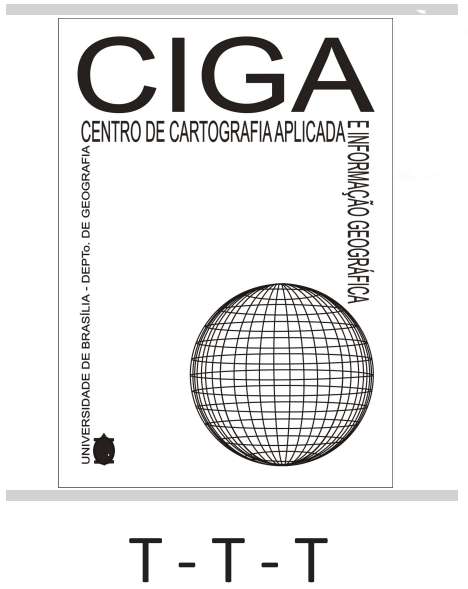

Revista Eletrônica:

Tempo - Técnica - Território,

V.3, N.2 (2012), 35:47

ISSN : 2177-4366

DOI: https://

doi.org/10.26512/

ciga.v3i2.15448
Como citar este artigo:

ANJOS, R. S. A. DIASPORA AFRICA-BRAZIL \& OF CANDOMBLÉ SPACE: SOME REFERENCES. Eletronic Magazine: Time - Technical - Territory, v.3, n.2 (2012), p. 31:42 ISSN: 2177-4366. DOI: https://doi.org/10.26512/ciga.v3i2.15448

available in: http://inseer.ibict.br/ciga/index.php/ciga/article/viewFile/139/105

Este obra está licenciado com uma Licença Crea tive Commons Atribuição-NãoComer cial 4.0 Inter nacional. 


\title{
DIASPORA AFRICA-BRAZIL \& OF CANDOMBLÉ SPACE: SOME REFERENCES
}

\author{
Prof. Dr. Rafael Sanzio Araújo dos Anjos \\ Center ofAppliedCartographyandGeographic Information \\ Departmentof Geography-University of Brasilia-University Campus-Asa Norte-Brasília- \\ DistritoFederal-Brazil. CEP.70.910-900. E-mail: cartografia@unb.br \\ Sites: www.unb.br/ih/ciga /www.rafaelsanziodosanjos.com.br \\ Tradução Inglês: Isabela Catatrina de Souza
}

RESUMO: Uma das questões estruturais relacionada à cultura africana no Brasil que continua merecendo investigação e conhecimento, está relacionada aos aspectos historiográficos e geográficos da formação, distribuição e resistências no espaço e da população de ancestralidade na África do território brasileiro. O paper resgata as principais referências da diáspora África-América-Brasil e configura a expressão espacial de alguns terrieros de candomblé na cidade de Salvador - Bahia. O pensamento social preconceituoso e o desconhecimento da população do país, no que se refere ao continente africano, continuam sendo um dos entraves estruturais para uma perspectiva real de respeitos às diferenças éticas, sobretudo as territorializadas, assim como, a criação no setor decisório, das condições necessárias para a implementação de políticas públicas mais articuladas e eficazes.

Palavras Chave: Geografia Afro-Brasileira, Território Étnico; População de matriz africana; Candomblé; Cartografia africana; Diáspora África-Brasil.

\begin{abstract}
One of the structural issues related to the African culture in Brazil that still deserves investigation and knowledge is related to the historiographic and geographic aspects of formation and distribution of the African descendent population in the Brazilian territory. This paper rescues the main references of the Africa-AmericaBrazil Diaspora and setsthe spatial expressionof someterreiros of candomblé in the city ofSalvador - Bahia. The social thinking bigoted and ignorance of the population, with regard to Africa, remain one of the structural impediments to a real prospect of ethical respect for differences, especially the spatial distribution, as well as the creation in the sector decision-making conditions necessary for the implementation of public policies most articulate and effective.
\end{abstract}

Key Words: African-Brazilian Geography; Ethnic Territory; African matrixed population; Candomblé; African Cartography; Africa-Brasil Diaspora. 


\section{INTRODUCTION}

Brazil is the contemporary political unit that records the highest statistics import of forced population contingents Africans over the centuries XVI to XIX. Thus, the African territory is a key component to a more accurate understanding of the issues surrounding the role of people of African descent in Brazilian society. So even if they needed more consistent interpretations of the origins of their populations in the early days of its formation, a better understanding and representation of the dynamics of this diaspora in space and a better configuration of their ancestral territorial identity. Despite this historical reference of African origin in this country, incorporating true, respect and space of African culture in Brazil remains one of the country structural issues that deserve further research, knowledge and action. Accordingly, the demands for understanding the complexities of the dynamics of our society are great and there are few disciplines better placed than the geography and mapping to assist in the representation and interpretation of the many questions that historical moment.

Geography is the science of the territory and this essential component, the land, the terreiro in a broad sense, remains the best instrument for observing what happened, because it shows the marks of historicity space, what is happening, this has registered agents working in current geographic configuration and what may happen, or you can capture the dynamic lines of the territorial forces and show the possibilities of the structure of space in the near future. The territory is in essence a physical fact, political, social, categorizable, possible sizing, where generally, the State is present and the cultural references are recorded and symbolic of the population. We cannot lose sight of that geography is the area of knowledge that is committed to making the world and its dynamics understandable for society to give explanations to the territorial transformations and identify solutions for better organization of space. Geography is, therefore, a fundamental discipline in citizenship formation of the Brazilian people, which presents a unique diversity in its ethnic composition, socioeconomic and spatial distribution.

The maps, are graphical representations of the real world, stay themselves as effective tools of interpretation and reading of the territory, allowing reveal the 
territoriality of social constructions and natural features of space and, rightfully so, show the geographical facts and their conflicts. These enable graphically reveal what happens in the dynamics of space and become increasingly indispensable, because they constitute a bridge between the observation levels of reality and simplification, reduction, explanation and clues to making decisions and solutions to problems. We cannot lose sight of what a map is not the territory, but that the products of cartography are the best possibilities of representation and reading the history of the territory.

In this paper we seek to assist in aggrandize information about the secular displacements Africa-America-Brazil and the territoriality of the terreiros of African religious resistance, especially Candomblé, taking as an example the city of Salvador in Bahia. This work is part of one of the steps operationalized in the Afro-Brazilian Geography Project: Education \& Planning of the Territory, developing in the Center of Applied Cartography and Geographic Information (CIGA) of the Department of Geography at the University of Brasilia. With these references seek to effectively contribute to the expansion of knowledge and continuity of discussions, where the ethnic-racial issue in Brazil is treated more seriously.

\section{THE DISPLACEMENTS AFRICA - BRAZIL - AN INTRODUCTION}

The historical movement of great navigations should be understood as a direct consequence of the process of geographical territorial domination developed, matured and implemented by European continent. The geographic horizon of its land area will be expanded significantly by new encounters of cultures, identities and territorialities. As a result, the world map will be profoundly changed in the XV, XVI, XVII, XVIII and XIX centuries, especially by the new territories to it incorporated and the "new" boundaries established and enforced. This period of human history will be characterized by a new phase of relations between them and nature. The tropics were seen by Europe as a world that could offer a suite of products that did not exist in their continent and this strategy represented a stimulus to mercantilist policy, the development of commercial capitalism and the strengthening of the state.

It is important to remember that the geographical concept of diaspora has to do with the reference of the dispersion of a people and their cultural and technological matrices. Throughout history we can identify the construction of territories by motilities 
of migration, both voluntary as forced migration. In Africa, we can characterize some of these large demographic movements, starting the first Diaspora, which corresponds to the spatial process of ancient settlement and occupation of the continent itself, and later to other land area of the world. The spatial phenomenon that we approach in this opportunity is linked to the centuries of displacement, usually called "slave traffic" to America (New World), the result of long periods of forced migration from the African continent, propellant context of the slave system and fundamental basis of primitive capitalism. The sequence of thematic maps shows a graphical representation of territorial references of African origin in four centuries of trafficking of people and disintegration of societies and States.

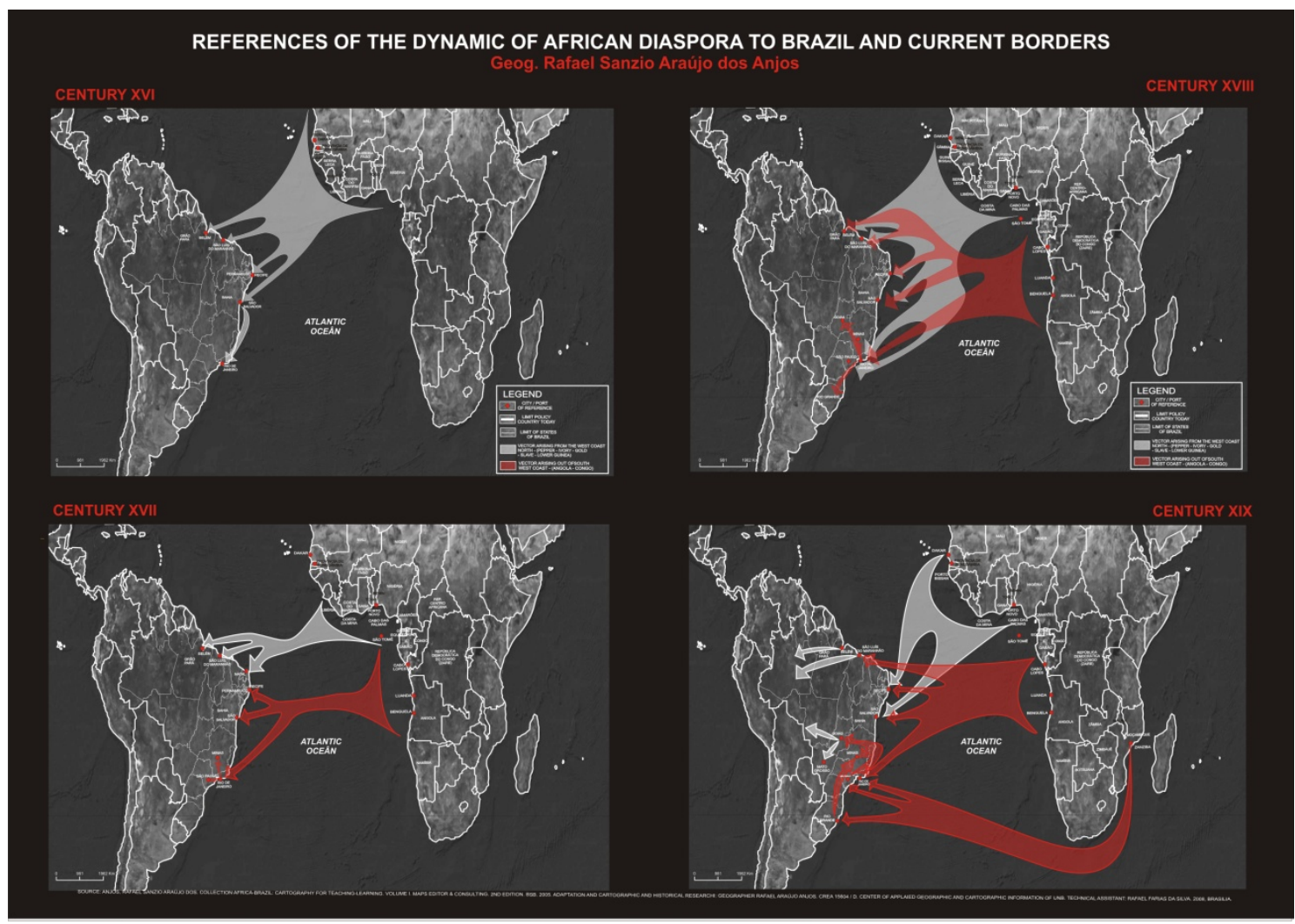

Some geographic considerations of population originating from sub-Saharan Africa with records in Brazil are topics treated in the following item.

\section{THE PRECARIOUS REFERENCES OF DISTRIBUTION OF AFRICAN POPULATION AND AFRO-BRAZILIAN IN THE TERRITORY OF BRAZIL COLONY}


The spraying process of different African origin on the extensions of the colony territory had also, as a strategy, hampering the organization, extinguish the native language and disabling the continuity of cultures, that is, actual devices have been created so that people from Africa lose their identity references and, therefore, there was a dilution of African ethnic identity in Brazil. Are "brought" to constitute the formation, expansion and effective occupation of Brazilian territory humans: Mines, Congos, Ombundos, Bacongos, Ovibundos, Monjolos, Balundos, Jeje, Angolas, Anjicos, Lunda, Quetos, Hausa, Fulani, Ijexás, Jalofos, Mandinga, Anagôs, Fons, Ardas, among many others, that enabled what we can simply call the african-Brazilian Brazilian population of African or of African descent. For example, populations of Bantu matrix, originated in Central Africa and the Yoruba also called, Nagôs, from West African, show relevant records and features in the daily of "Real Brazil".

The country knows clearly that in the period between 1871 and 1920, 3.39 million European immigrants arrived at the country, of which 1,373,000 were Italians, 901,000, Portuguese, and 500,000, Spanish. Many Europeans in Brazil will occupy territories which were already established African populations or their descendants, as, for example, the occupation of Italian immigrants (1880) at the site of Sapucaí, in the Greater Quilombo of Campo Grande, in the oldest province of Minas Gerais. It is important to note that this number is approaching nearly 4 million Africans were taken from their natural habitat and officially brought to Brazil between 1520 and 1850. That's because the references spatial, temporal and quantitative period of clandestine trafficking are yet to be characterized by Brazilian historiography.

This is another geographical factor that contributes to the lack of an ancestral reference home of the Brazilian population of African reference, with profound interference in their citizenship and sense of belonging land. Claiming to this quota that their ancestors were "brought" from the African continent is vague, without consistency, disrespectful, when it comes to a length of over 30 million $\mathrm{km}^{2}$, with territorial contexts of hundreds of ancient kingdoms, empires and ethnic groups unknown to the official historiography of the country. This secular demand, which would allow a spatial connection more referenced and more precise in Africa, remains unanswered and no prospect of satisfactory institutional solution. Thus, a major challenge of the research aimed at territorial African diaspora is in the silence of the traffic statistics and in the 
identification of territorial reference, therefore, the place of origin of African groups who entered in Brazil. The languages and religions of Africa are references of secular survivals that have managed to stay in the territory and in social relations, despite the repression and institutionalized discrimination.

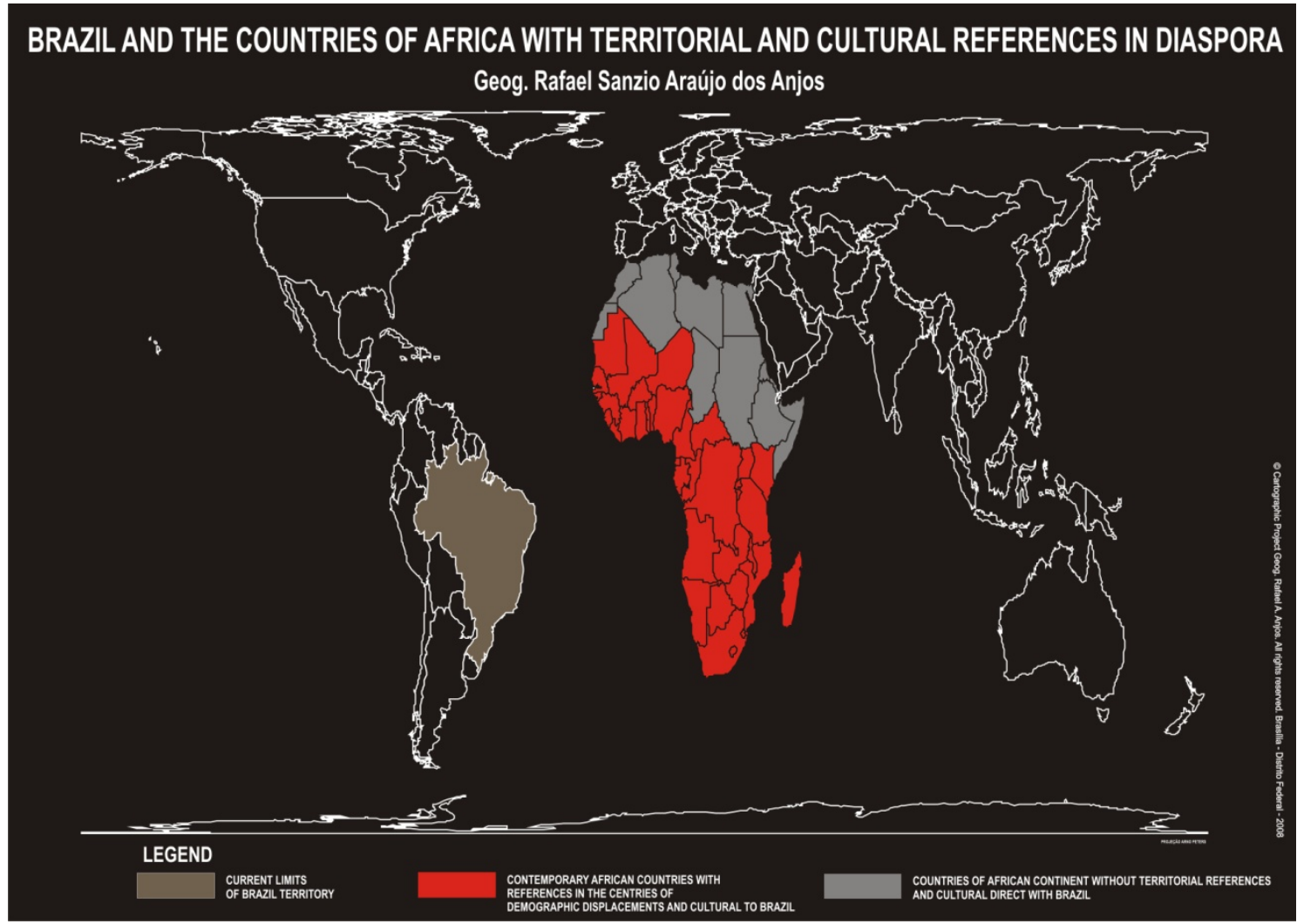

It is important to emphasize that the African sub-Saharan populations were not solely responsible for the effective occupation of Brazilian territory and by hand labor, and they scored and mark, in an irreversible way, to our social formation, technological, demographic and cultural, to throughout these centuries, has been preserved and recreated, even contrary to the policies of the system. Several sectors of contemporary Brazilian population are victims of discrimination and prejudices of all kinds. Among the types of discrimination, ethnic, affecting particularly the contingent of African descent in the country is undoubtedly the greatest extent of social and territorial cohesion, due to the large demographic expression. If we take as an example, the spaces of Candomblé in colonies metropoles (São Salvador of Bahia, Sao Luis of Maranhão, Saint Sebastian of Rio de Janeiro, Belém of Pará, among others), the records of the oldest terreiros are on the urban fringe and with rare exception, in central areas and valued of the city. This space fact is a revealing of the actual process of exclusion and "invisibility" of one of most significant reference of the African Diaspora in Brazil, the 
territoriality of religious resistance. If we determine the secular spaces of many of these of survivals in dynamic growth and urban transformation, some geographical aspects can be detected, such as:

1. The standard typological more uniform, ie, the types of housing popular with little variations of morphology (height of buildings), reveal a drive socioeconomic in the communities, a fact that lessens the conflict in the wealthpoverty relation. Spatial component that "adds" to the urban territoriality;

2. The high spatial density of buildings (houses, small plots and with almost no green area) shows the possibility of correspondence in the high number of people (7-8 people or more) for housing. This is important in strengthening the community in its structural demands. There are not spaces "cold-isolatedsolitary" as in areas of large homes of the upper class;

3. Green spaces that remain within the oldest terreiros and its surroundings, pointing to their importance in the preservation and maintenance of urban environmental, overcoats, the peripheral, more excluded of the investments in infrastructure in the city;

4. For the topographical and religious issue, some sites are on a slope that lies (or found) with an element hydrographic (river, creek, stream, pond, lake, dam, etc.). Some of these valleys became avenues and its hydrography was canalized and rectified, ie their natural courses no longer exist nor accessibility in religious communities, with the exception of those who have managed to maintain and withstand the pressure and disfigurement of the landscape by urbanization.

On item below are some cartographic images of territoriality of Candomblé in Salvador, where the aspects mentioned above can be verified.

\section{TERREIROS OF CANDOMBLÉS VIEWED FROM TOP: EXAMPLES IN THE CITY OF SALVADOR - BAHIA}

Initially, I excuse and permission to all of the Orixás of Terreiros of São Salvador of Bahia, shown in this part of the paper, recommending that spatial information may serve to enhance and extend respectability by African origin in Brazil. I also ask the blessing of Priestesses and Priests to be revealing this "Cartography of the Candomblés," neglected and despised for so many centuries by the dominant system, 
particularly by the African mystification of sacred space in Brazil. I remember that a significant part of "fear" is due to lack of information. And the lack of information breeds prejudice and this is one of the main challenges of African Contemporary Brazil: report to alleviate the fears and thus "diluting" the forces of prejudice and ensure the survival and secular resistance. This reference helps us understand why so many resistances to complete insertion of the population of African origin in "Brazil Included". The secular practice of maintaining the Brazilian Africa in "Brazil Excluded" has built and solidified bases in "Brazil Colony" and therefore a delayed State, ie with a narrow mentality of their complex society.

The aerial images are powerful because prey on the "look addict" of our brain, accustomed to a horizontal view. The vertical outlet (like a plane or helicopter), enables discovery and identification of new elements in the territory and in turn a more complete understanding of space and wider known and lived. This is a precarious reference _ of our citizenship. Everyone should know and do good read of the maps and spatial images of geographical space. This exclusion is part of the strategies surviving colonies of restriction to knowledge of the territory by the society, in the broad sense.

Could use as an example in this item, a big Brazilian cities with colonial legacy slavery. The African religious arrays are present in all of them, without exception. We advocate not perform thorough analyzes of images, especially to avoid the risk of being restrictive in the range of readings that are made possible spaces of the Territories of candomblés.

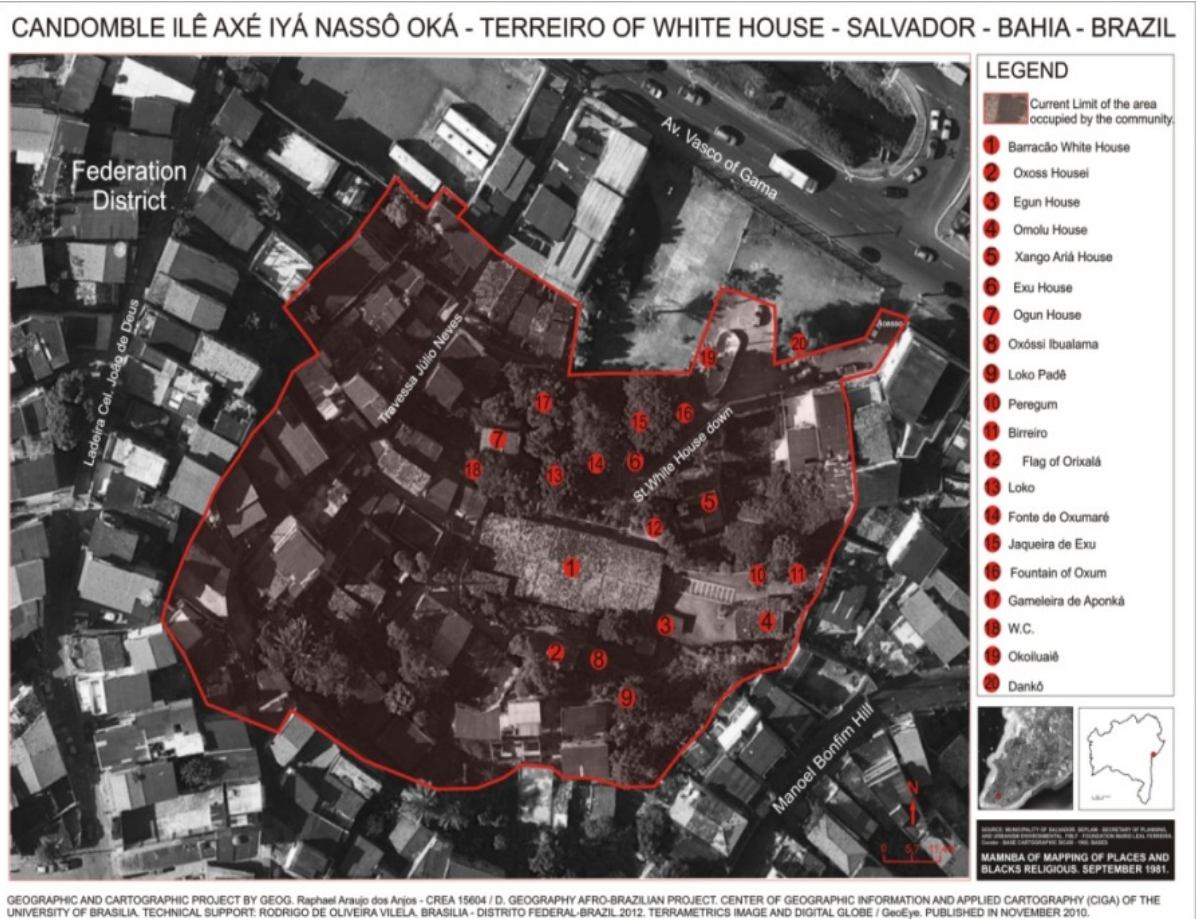




\section{CANDOMBLÉ ILÊ IYA OMIN AXÉ IYAMASSÊ - TERREIRO OF GANTOIS SALVADOR - BAHIA - BRAZIL}

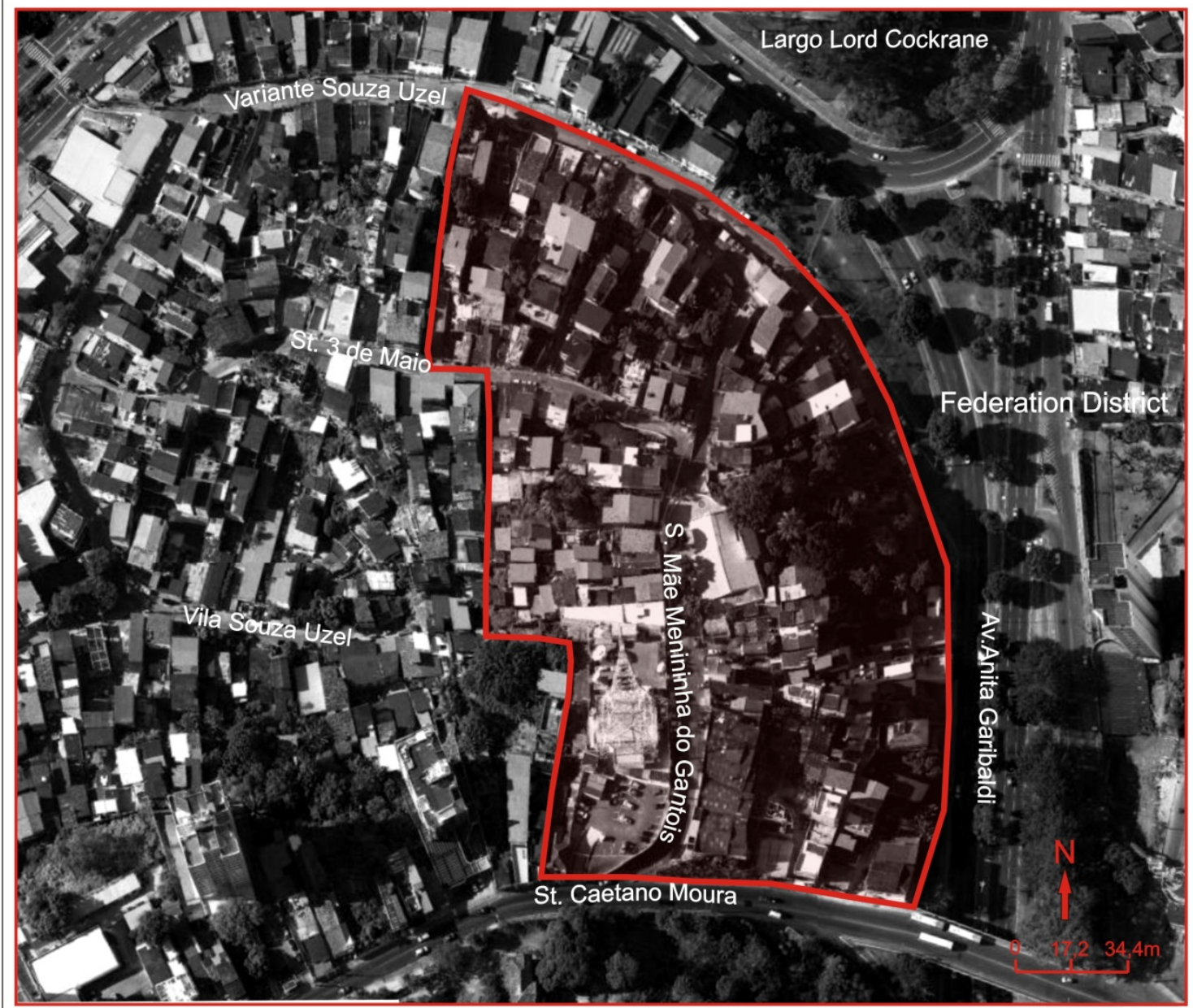

\section{LEGEND}

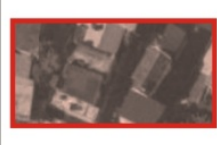

LIMIT OF THE AREA OF CULTURAL PROTECTION AND LANDSCAPE - TERREIRO OF GANTOIS
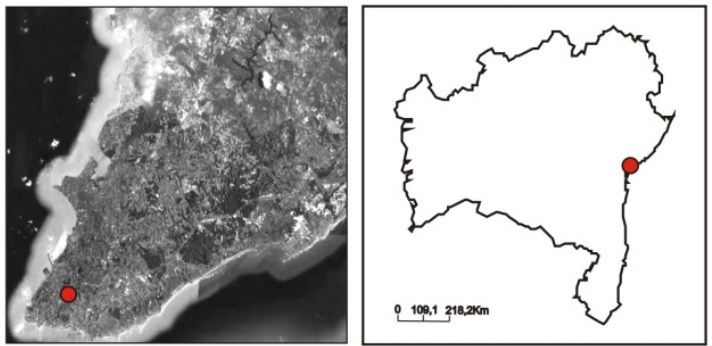

GEOGRAPHIC AND CARTOGRAPHIC PROJECT BY GEOG. Raphael Araujo dos Anjos - CREA 15604 / D. PROJECT AFRO-BRAZILIAN GEOGRAPHY. CENTER OF GEOGRAPHIC INFORMATION AND MAPPING APPLIED (CIGA) OF THE UNIVERSITY OF BRASILIA. TECHNICAL SUPPORT: RODRIGO DE OLIVEIRA VILELA. BRASILIA - BRAZIL-DISTRITOFEDERAL. 2012. TERRAMETRICS PICTURE AND DIGITAL GLOBE / GeoEye. PUBLISHED IN NOVEMBER 2010.

SOURCE: MUNICIPALITY OF SALVADOR. SEPLAM - SECRETARY OF PLANNING, URBANISM AND ENVIRONMENTAL. FMLF - FOUNDATION MARIO LEAL FERREIRA. CONDER - BASE CARTOGRAPHIC SICAR - 1992. GRAPHICS BASES OF THE MUNICIPAL GOVERNMENT EDITED OF SALVADOR. 


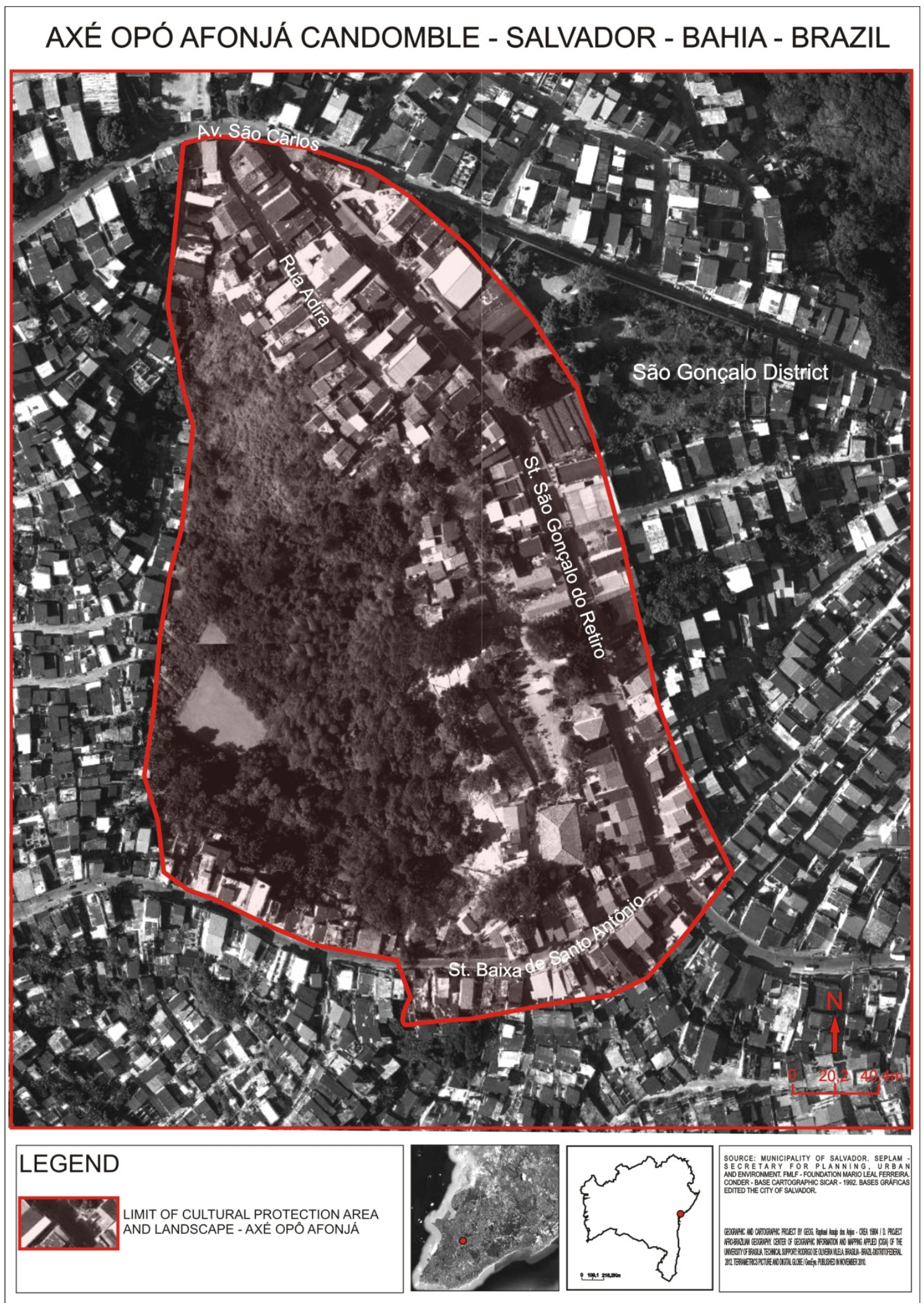

Eletronic Magazine: Time - Technical - Territory, V.3, N.1 (2012), 35:47 ISSN: 2177-4366 


\section{CONCLUSIONS AND RECOMMENDATIONS}

Considering that analytical constructions and speculation are not exhaustedwe concluded and we recommend the following:

- Statistics show Brazil as the second largest black nation on the planet and it is with respect to that population statistics are computed more discriminatory and socioeconomic depreciation. You cannot hide that we have more social, economic, secular territorial and structural, for which the "remedies" are still coming and the issues are pushed to another day, next week, next month, next year that never comes. And the centuries are passing! Thus, be descended of the African continent in Brazil, secularly remains a risk factor, a challenge to the maintenance of human survival, an extra effort to be visible in the dominant system and, above all, put an additional energy to be - to be inserted. It is a struggle against the secular territorial exclusion, social and economic;

- The question of ignorance of the Brazilian population in respect to Africa continent is an obstacle to a real prospect of widespread respect for ethnic differences in the country. We cannot lose sight that the main obstacles created by the system to insert the population of African origin in Brazilian society, is the degradation of this in teaching. That context can only change with a more aggressive educational policy (we are not dealing with violence, but political expression in action) and with the focus directed to demystify Africa for the population of Brazil. The Brazilian cannot be thinking that Africa is a country, nor find that there are only diseases; humans and primitive cultures; areas for safari and exotic animals, etc.. The main damage that misinformation is to assist in maintaining a population prejudiced references to Africa and be an immediate association to afro-Brazilian. This is a structural point for a process of change, where the Brazilian human being of African descent is actually more respected in the system. A big part of the problem remains, misinformation, ie the position of Africa, usually one of the last continents in textbooks and official needs to be changed;

- Another structural issue, still directed to the decision making in Brazil refers to the creation of necessary conditions for the holding of a census that portrays 
realistic and best Brazilian ethnic diversity. This issue is complex because it means changing the methods of measuring population and therefore the possibility of an official record of an "African Brazil" so far no evidence and "invisible".

- We take as a premise that information alone does not mean knowledge. However, it reveals that with the aid of science and technology, we are able to collaborate in modifying specific policies in order to support the adoption of concrete measures to change, structurally, the situations of the people of "African Brazil".

\section{BIBLIOGRAPHIC REFERENCES}

ANJOS, R. S. A. “ A África, a geografia, o tráfico de povos africanos e o Brasil. Revista Palmares em Ação. Brasília: Fundação Cultural Palmares - MINc. Ano 1 No.2 : 56-66, 2002

“Coleção África-Brasil: Cartografia para o ensino-aprendizagem”. Brasília: Mapas Editora\& Consultoria, 2ª Edição. 2005 - BsB - DF.

ANJOS, R.S.A \& CYPRIANO, A. “Quilombolas - tradições e cultura da resistência”. Aori Comunicações. Petrobras, 2006. São Paulo, 240 p.’`

ANJOS, R.S.A. Coleção África-Brasil: Cartografia para o ensino-aprendizagem. Volume II Brasília: Mapas Editora\& Consultoria, Brasília, 2007.

África-Quilombos-Brasil: Átlas Geográfico. Relatório Final de PósDoutorado em Cartografia Étnica. Universidade de Brasília - GEA - CIGA / CNPQ / Museu Real da África Central MRAC - Tervuren. Bruxelas - Bélgica, 2008.

Quilombos: Geografia Africana-Cartografia Étnica-Territórios Tradicionais. Mapas Editora\& Consultoria, 190p. Brasília, 2009

Territorialidade Quilombola: Fotos \& Mapas / Quilombola Territoriality: Photos \& Maps. Mapas Editora \& Consultoria., 124 p. Brasília, 2011

CASTRO, Y. P. “Falares africanos na Bahia - um vocabulário afro-brasileiro". Academia Brasileira de Letras. Rio de Janeiro: Topbooks, 2001, 366p.

IBGE. Pesquisa Nacional por Amostra de Domicílio. Rio de Janeiro: IBGE - PNAD, 1996

MELO, A. Setenta e cinco por cento dos escravos levados para o Brasil eram Bantu. Jornal de Angola, 10/9/2008. Luanda - Angola.

PMS. OCEPLAN - Projeto MAMNBA - Mapeamento de Sítios e Monumentos Religiosos Negros na Bahia. Relatório Técnico. Salvador, 1981 